\title{
MENCARI MODEL PENDIDIKAN KARAKTER DI SEKOLAH
}

\author{
M. Fahim Tharaba \\ Universitas Islam Negeri Maulana Malik Ibrahim \\ e-mail: fahimtarbiyah@pai.uin-malang.ac.id
}

\begin{abstract}
The focus of this research is looking for a character education model that was developed on the research site (MAN 3 Malang, SMAN 1 Malang and MA Pondok Pesantren An-Nur Malang Regency). The study used a qualitative approach or in the field of education is often called the naturalistic approach with purposif sampling techniques and snowball sampling techniques as well as sampling time (time sampling). The results of this research are as follows: (1) prioritized values in character education i.e. religious character, honest, discipline, hard work, tolerance, independent, love of homeland, democracy, cooperation, creative, taste of Inging Tau, appreciating achievement; (2) Character education models are conducted through integration into the learning activities of each subject; (3) Character Education Model is done through habituation in daily life in school/Madrasah and integration into school management activities/Madrasah; (4) Character education models are conducted through integration with extra-curricular activities on all three research sites; and (5) constraints encountered in the implementation of character education and solution of its resolution on the three research sites, namely in MA An-Nur Bululawang. The position of the attend which is at one Pesantren Foundation, which makes the policy making should always seek approval from the Pesantren. In addition, the time division of activities is also a constraint. While the character education in the MAN 3 Malang is considered as less effective because it can not be converted in real time in the book Raport and lack of monitoring and evaluation, so that the character education is still limited to normative. While the obstacles faced at SMAN 1 Malang in the form of lack of control and support from the student family, so that each child at home back "loose" can not be monitored as done in the Madrasah.
\end{abstract}

Keywords. Model; Character Education

Abstrak. Fokus penelitian ini adalah mencari model pendidikan karakter yang dikembangkan pada situs penelitian (MAN 3 Malang, SMAN 1 Malang dan MA Pondok Pesantren An-Nur Kabupaten Malang). Adapun penelitian ini menggunakan pendekatan kualitatif atau dalam bidang pendidikan sering disebut pendekatan naturalistic dengan teknik sampling secara purposif dan teknik sampling bola salju (snowball sampling) serta sampling waktu (time sampling). Hasil penelitian ini sebagai berikut: (1) Nilai-nilai yang diprioritaskan dalam pendidikan karakter yaitu karakter Religius, Jujur, Disiplin, Kerja Keras, Toleransi, Mandiri, Cinta Tanah Air, Demokrasi, Kerjasama, Kreatif, Rasa Inging Tau, Menghargai Prestasi; (2) Model pendidikan karakter dilakukan melalui integrasi ke dalam kegiatan pembelajaran pada masingmasing mata pelajaran; (3) Model pendidikan karakter dilakukan melalui pembiasaan dalam kehidupan keseharian di sekolah/madrasah dan integrasi ke dalam kegiatan pengelolaan sekolah/madrasah; (4) Model pendidikan karakter dilakukan melalui integrasi dengan kegiatan-kegiatan ekstra kurikuler pada ketiga situs penelitian; dan (5) Kendala-kendala yang dihadapi dalam implementasi pendidikan karakter dan solusi pemecahaannya pada ketiga situs penelitian, yaitu di MA An-Nur Bululawang. Posisi madarasah yang berada pada satu yayasan pesantren, yang menjadikan pengambilan 
kebijakan harus selalu meminta persetujuan dari pihak pesantren. Selain itu, pembagian waktu kegiatan juga menjadi kendala tersendiri. Sementara pendidikan karakter yang ada di MAN 3 Malang dianggap kurang berjalan secara efektif karena tidak bisa dikonversikan secara riil pada buku raport dan kurangnya monitoring dan evaluasi, sehingga pendidikan karakter ini masih sebatas normatif saja. Sedangkan kendala yang dihadapi di SMAN 1 Malang berupa minimnya kontrol dan dukungan dari pihak keluarga siswa, sehingga setiap anak pada saat di rumah kembali "lepas" tidak bisa dipantau sebagaimana yang dilakukan di madrasah.

Kata Kunci. Model; Pendidikan Karakter

Copyright (C JMPI: Jurnal Manajemen Pendidikan Islam. All Right Reserved.

This is an open access article under the CC BY-SA 4.0 license

(https:// creativecommons.org/licenses/by-sa/4.0/)

\section{A. PENDAHULUAN}

Eksistensi suatu bangsa sangat ditentukan oleh karakter yang dimiliki. Hanya bangsa yang memiliki karakter kuat yang mampu menjadikan dirinya sebagai bangsa yang bermartabat dan disegani oleh bangsa-bangsa lain. Oleh karena itu, menjadi bangsa yang berkarakter adalah keinginan bangsa Indonesia. Keinginan ini sebenarnya sudah lama tertanam pada bangsa Indonesia. Para pendiri negara menuangkan keinginan itu dalam Pembukaan UUD 1945 alinea ke-2 dengan pernyataan yang tegas, yaitu: "...mengantarkan rakyat Indonesia ke depan pintu gerbang kemerdekaan negara Indonesia, yang merdeka, bersatu, berdaulat, adil dan makmur". Para pendiri negara menyadari bahwa hanya dengan menjadi bangsa yang merdeka, bersatu, berdaulat, adil dan makmurlah bangsa Indonesia menjadi bermartabat dan dihormati bangsabangsa lain.

Setelah Indonesia merdeka, keinginan tersebut terus dikumandangkan oleh pemimpin nasional. Soekarno senantiasa membangkitkan semangat rakyat Indonesia untuk menjadi bangsa yang berkarakter dengan ajakan berdikari, yaitu berdiri di atas kaki sendiri. Soekarno mengajak bangsa dan seluruh rakyat Indonesia untuk tidak bergantung pada bangsa lain, melainkan harus menjadi bangsa yang mandiri. Ajakan untuk menjadi bangsa yang mandiri ini dilanjutkan dengan Trisakti, yaitu kemandirian di bidang politik, ekonomi, dan budaya.

Semangat untuk menjadi bangsa yang berkarakter ditegaskan oleh Soekarno dengan mencanangkan nation and character building dalam rangka membangun dan mengembangkan karakter bangsa Indonesia guna mewujudkan cita-cita bangsa, yaitu masyarakat yang adil dan makmur berdasarkan Pancasila. Secara spesifik Soekarno menegaskan dalam amanat Pembangunan Semesta Berencana tentang pentingnya karakter ini sebagai mental investment, yang mengatakan bahwa kita jangan melupakan aspek mental dalam pelaksanaan pembangunan dan mental yang dimaksud adalah mental Pancasila.

Pada masa orde baru, keinginan untuk menjadi bangsa yang bermartabat tidak pernah surut. Soeharto, sebagai pemimpin orde baru, menghendaki bangsa Indonesia senantiasa bersendikan pada nilai-nilai Pancasila dan ingin menjadikan warga negara Indonesia menjadi manusia Pancasila melalui penataran P-4 (Pedoman Penghayatan dan Pengamalan Pancasila). Secara filosofis penataran ini sejalan dengan kehendak pendiri negara, yaitu ingin menjadikan rakyat Indonesia sebagai manusia Pancasila. 
Namun, secara praksis penataran ini dilakukan dengan metodologi yang kurang tepat karena menggunakan cara-cara indoktrinasi dan tanpa keteladanan yang baik dari para penyelenggara Negara, sehingga pada akhirnya penataran P-4 ini mengalami kegagalan, meskipun telah diubah pendekatannya dengan menggunakan pendekatan kontekstual.

Pada masa reformasi keinginan membangun karakter bangsa terus berkobar bersamaan dengan munculnya euforia politik sebagai dialektika runtuhnya rezim orde baru. Keinginan menjadi bangsa yang demokratis, bebas dari korupsi, kolusi dan nepotisme $(\mathrm{KKN})$, menghargai dan taat hukum merupakan beberapa karakter bangsa yang diinginkan dalam kehidupan bermasyarakat, berbangsa dan bernegara. Namun, kenyataan yang ada justru menunjukkan fenomena yang sebaliknya. Konflik horizontal dan vertikal yang ditandai dengan kekerasan dan kerusuhan muncul di mana-mana, diiringi mengentalnya semangat kedaerahan dan primordialisme yang bisa mengancam integrasi bangsa. Praktik KKN tidak semakin surut malahan semakin berkembang. Demokrasi penuh etika yang didambakan berubah menjadi demokrasi yang kebablasan dan menjurus pada anarkisme. Kesantuan sosial dan politik semakin memudar pada berbagai tataran kehidupan bermasyarakat, berbangsa, dan bernegara. Kecerdasan kehidupan bangsa yang dimanatkan para pendiri negara semakin tidak tampak, semuanya itu menunjukkan lunturnya nilai-nilai luhur bangsa.

Di kalangan pelajar dan mahasiswa dekadensi moral tersebut tidak kalah memprihatinkan. Perilaku melanggar etika, moral dan hukum dari yang ringan sampai yang berat masih sering diperlihatkan oleh pelajar dan mahasiswa. Kebiasaan 'menyontek' pada saat ulangan atau ujian masih dilakukan. Keinginan lulus dengan cara mudah dan tanpa kerja keras pada saat ujian nasional menyebabkan mereka berusaha mencari jawaban dengan cara tidak beretika. Mereka mencari 'bocoran jawaban' dari berbagai sumber yang tidak jelas. Apalagi jika keinginan lulus dengan mudah ini bersifat institusional karena direkayasa atau dikondisikan oleh pimpinan sekolah dan guru secara sistemik. Pada mereka yang tidak lulus, ada di antaranya yang melakukan tindakan nekad dengan menyakiti diri atau bahkan bunuh diri. Perilaku tidak beretika juga ditunjukkan oleh mahasiswa. Plagiarisme atau penjiplakan karya ilmiah di kalangan mahasiswa juga masih bersifat massif. Bahkan ada yang dilakukan oleh mahasiswa program doktor. Semuanya itu menunjukkan kerapuhan karakter di kalangan pelajar dan mahasiswa. Maka diperlukan konsep penanaman karakter anti korupsi sejak dini untuk mencegah perilaku korupsi di masa mendatang (Trisnawati, 2020).

Hal lain yang menggejala di kalangan pelajar dan mahasiswa berbentuk kenakalan. Beberapa di antaranya adalah tawuran antar pelajar dan antar mahasiswa. Di beberapa kota besar tawuran pelajar menjadi tradisi dan membentuk pola yang tetap, sehingga di antara mereka membentuk 'musuh bebuyutan'. Tawuran juga sering dilakukan oleh para mahasiswa seperti yang dilakukan oleh sekelompok mahasiswa pada perguruan tinggi tertentu di Makassar. Bentuk kenakalan lain yang dilakukan pelajar dan mahasiswa adalah meminum minuman keras, pergaulan bebas, dan penyalahgunaan narkoba yang bisa mengakibatkan depresi bahkan terkena HIV/AIDS. Fenomena lain yang mencoreng citra pelajar dan lembaga pendidikan adalah maraknya 'gang pelajar' dan 'gang motor'. Perilaku mereka bahkan seringkali menjurus pada tindak kekerasan (bullying) yang meresahkan masyarakat dan bahkan tindakan 
kriminal seperti penganiayaan, bahkan pembunuhan. Semua perilaku negatif di kalangan pelajar dan mahasiswa tersebut di atas menunjukkan kerapuhan karakter yang cukup parah yang salah satunya disebabkan oleh tidak optimalnya pengembangan karakter di lembaga pendidikan di samping karena kondisi lingkungan yang tidak mendukung (Taulabi dan Mustofa, 2019).

Untuk itu perlu dicari jalan terbaik untuk membangun dan mengembangkan karakter manusia dan bangsa Indonesia agar memiliki karakter yang baik, unggul dan mulia. Upaya yang tepat untuk itu adalah melalui pendidikan, karena pendidikan memiliki peran penting dan sentral dalam pengembangan potensi manusia, termasuk potensi mental. Melalui pendidikan diharapkan terjadi transformasi yang dapat menumbuh kembangkan karakter positif, serta mengubah watak dari yang tidak baik menjadi baik. Ki Hajar Dewantara dengan tegas menyatakan bahwa "pendidikan merupakan daya upaya untuk memajukan bertumbuhnya budi pekerti (kekuatan batin, karakter), pikiran (intellect), dan tubuh anak". Lebih lanjut, Ki Hajar Dewantara mengatakan "Ing ngarso sung tulodho (di depan memberi contoh dan tauladan), Ing madya mangun karso(di tengah memberi kesempatan untuk mengembangkan diri), tut wuri handayani (di belakang mendorong)" (Abrori, 2018). Jadi jelaslah, pendidikan merupakan wahana utama untuk menumbuhkembangkan karakter yang baik. Di sinilah pentingnya pendidikan karakter.

Pendidikan karakter sebenarnya bukan hal yang baru. Sejak awal kemerdekaan, masa orde lama, masa orde baru, dan masa reformasi sudah dilakukan dengan nama dan bentuk yang berbeda-beda. Namun hingga saat ini belum menunjukkan hasil yang optimal, terbukti dari fenomena sosial yang menunjukkan perilaku yang tidak berkarakter sebagaimana disebut di atas. Dalam Undang-undang No. 20 tahun 2003 tentang Sistem pendidikan Naional telah ditegaskan bahwa "pendidikan nasional berfungsi mengembangkan kemampuan dan membentuk watak serta peradaban bangsa yang bermartabat dalam rangka mencerdaskan kehidupan bangsa, bertujuan untuk berkembangnya potensi peserta didik agar menjadi manusia yang beriman dan bertakwa kepada Tuhan Yang Maha Esa, berakhlak mulia, sehat, berilmu, cakap, kreatif, mandiri, dan menjadi warga negara yang demokratis serta bertanggung jawab". Namun tampaknya upaya pendidikan yang dilakukan oleh lembaga pendidikan dan institusi pembina lain belum sepenuhnya mengarahkan dan mencurahkan perhatian secara komprehensif pada upaya pencapaian tujuan pendidikan nasional.

Di tengah kegelisahan yang menghinggapi berbagai komponen bangsa, sesungguhnya terdapat beberapa lembaga pendidikan atau sekolah yang telah melaksanakan pendidikan karakter secara berhasil dengan model yang mereka kembangkan sendiri-sendiri. Mereka inilah yang menjadi best practices dalam pelaksanaan pendidikan karakter di Indonesia. Namun, hal itu tentu saja belum cukup, karena berlangsung secara sporadis atau parsial dan pengaruhnya secara nasional tidak begitu besar. Oleh karena itu, perlu ada gerakan nasional pendidikan karakter yang diprogramkan secara sistemik dan terintegrasi.

Mantan Menteri Pendidikan Nasional, Mohammad Nuh menegaskan, bahwa tidak ada yang menolak tentang pentingnya karakter, tetapi yang lebih penting adalah bagaimana menyusun dan mensistemasikan, sehingga anak-anak dapat lebih berkarakter dan lebih berbudaya. Dalam upaya menyusun dan mensistemasikan pendidikan karakter tersebut, maka perlu digali model-model pendidikan karakter 
sebagaimana yang diimplementasikan pada sekolah/madrasah tertentu yang - baik secara langsung atau tidak langsung - telah menerapkan pendidikan karakter.

Kemajuan sebuah bangsa lebih ditentukan oleh karakter penduduknya dan karakter penduduk dibina lewat pendidikan yang bermutu dan relevan, terutama pengembangan budaya Islami sekolah harus dilakukan secara terus-menerus oleh warga sekolah agar tujuan karakter yang ditentukan dapat tercapai dengan baik (Darmanto, 2019). Sehubungan dengan ini, MAN 3 Malang, SMAN 1 Malang dan MA Pondok Pesantren An-Nur Kabupaten Malang, merupakan 3 (tiga) institusi pendidikan yang dipandang maju dan bermutu di daerah Malang Raya.

Di ketiga situs penelitian tersebut pada dasarnya telah mengembangkan pendidikan Karakter. Di MAN 3 Malang terlihat pada cerminan yang diharapkan dari profil para civitas akademikanya, baik yang terkait dengan profil guru, pegawai, siswa maupun lulusannya. Di SMAN 1 Malang tercermin dalam visi dan misinya, pedoman sopan santun (etiket) baik di dalam maupun di luar sekolah, serta pedoman iman dan taqwa (IMTAQ). Sedangkan MA An-Nur Bululawang Malang merupakan madrasah yang menyatu dengan pondok pesantren, yang memiliki visi terbentuknya puteraputeri kader intelek ahlussunnah wal-jama'ah sholihin sholihat. Istilah "sholihin sholihat" menggambarkan cita-citanya untuk membentuk manusia yang memiliki kesalehan inidividu dan sosial. Komitmen sekolah dalam mewujudkan visi misa menjadi modal penting dalam meraih keberhasilan Pendidikan karakter (Trisnantari $\mathrm{dkk}, 2019)$.

Kenyataan tersebut mendorong peneliti untuk menggali dan mengkaji lebih mendalam mengenai apakah berbagai karakter yang diharapkan tersebut sudah difahami oleh segenap sivitas akademikanya dan diwujudkan dalam kehidupan keseharian di sekolah/madrasah sebagai budaya sekolah/madrasah, serta ditanamkan dan dikembangkan dalam kegiatan pembelajaran dan kegiatan ekstra kurikuler. Bagaimana model pendidikan karakter yang diterapkan pada ketiga situs penelitian, dan strategi mereka dalam mewujudkan berbagai karakter yang diharapkan tersebut.

Adapun tujuan penelitian ini adalah mendeskripsikan nilai-nilai yang diprioritaskan dalam pendidikan karakter pada ketiga situs penelitian, yang meliputi" (1) Mengetahui model pendidikan karakter yang dilakukan melalui integrasi ke dalam kegiatan pembelajaran pada masing-masing mata pelajaran pada ketiga situs penelitian; (2) Mengetahui model pendidikan karakter yang dilakukan melalui pembiasaan dalam kehidupan keseharian di sekolah/madrasah dan integrasi ke dalam kegiatan pengelolaan sekolah/madrasah pada ketiga situs penelitian; (3) Mengetahui model pendidikan karakter yang dilakukan melalui integrasi dengan kegiatan-kegiatan ekstra kurikuler pada ketiga situs penelitian; dan (4) Mendeskripsikan kendala-kendala yang dihadapi dalam implementasi pendidikan karakter dan solusi pemecahaannya pada ketiga situs penelitian.

Kilpatrick dan Lickona merupakan pencetus utama pendidikan karakter yang percaya adanya keberadaan moral absolut dan bahwa moral absolut itu perlu diajarkan kepada generasi muda agar mereka paham betul mana yang baik dan benar. Lickona (1992) dan Kilpatrick (1992) juga Brooks dan Goble tidak sependapat dengan cara pendidikan moral reasoning dan values clarification yang diajarkan dalam pendidikan di Amerika, karena sesungguhnya terdapat nilai moral universal yang bersifat absolut (bukan bersifat relatif) yang bersumber dari agama-agama di dunia, yang disebutnya 
sebagai "the golden rule". Contohnya adalah berbuat jujur, menolong orang, hormat dan bertanggung jawab.

Pendidikan karakter siswa di sekolah berarti berbagai upaya yang dilakukan oleh sekolah dalam rangka pembentukan atau pembangunan karakter siswa. Pendidikan karakter dapat dilakukan melalui program intrakurikuler maupun ekstrakurikuler (Ningsih, 2019). Terkait dengan sekolah, sekarang sedang digalakkan pembentukan budaya sekolah. Salah satu budaya yang dipilih sekolah adalah kultur akhlak (karakter) mulia (Mawardi dkk, 2020). Di negara-negara lain, kecenderungan pendidikan karakter telah lama dimulai. Larry P Nucci dan Darcia Narvaez (2008) menyatakan bahwa pada saat itu 80\% negara-negara Amerika Serikat telah menetapkan bahwa pendidikan Karakter adalah suatu keharusan. Mereka mengatakan bahwa pendidikan Karakter didasarkan pada kecenderungan masyarakat yang menyatakan bahwa sekolah-sekolah seharusnya mendukung tumbuhnya kejujuran di antara anakanak (97\%), menghargai yang lain (94\%), menjadi demokratis (93\%) dan menghormati yang lain yang berasal dari latar belakang sosial yang berbeda, dan seterusnya (93\%).

Di dalam buku "Pengembangan Pendidikan Budaya dan Karakter Bangsa", yang disusun oleh Tim Badan Penelitian dan Pengembangan Pusat Kurikulum Kementerian Pendidikan Nasional (2010), dinyatakan bahwa ada 18 (delapan belas) butir nilai karakter yang ditanamkan dan dikembangkan di sekolah, yaitu: "Nilai Religius, Nilai Jujur, Nilai Toleransi, Nilai Disiplin, Nilai Kerja keras, Nilai Kreatif, Nilai Mandiri, Nilai Demokratis, Nilai Rasa ingin tahu, Nilai Semangat kebangsaan, Nilai Cinta tanah air, Nilai Menghargai prestasi, Nilai Bersahabat/komunikatif, Nilai Cinta damai, Nilai Gemar membaca, Nilai Peduli lingkungan, Nilai Peduli sosial, dan Nilai Tanggung Jawab".

\section{B. METODE}

Tujuan penelitian ini adalah mencari model pendidikan karakter yang dikembangkan pada ketiga situs penelitian (MAN 3 Malang, SMAN 1 Malang dan MA Pondok Pesantren An-Nur Kabupaten Malang), dan untuk menjawab bagaimana sekolah/madrasah yang menjadi situs penelitian tersebut mengembangkan model pendidikan karakter, diperlukan pengamatan yang mendalam dalam situasi yang wajar (natural setting) yang dikenal dengan pendekatan kualitatif (Bogdan \& Biklen, 1992; Denzin \& Lincoln, 1994), atau dalam bidang pendidikan sering disebut pendekatan naturalistic (E.G. Guba \& Y.S Lincoln, 1981). Penelitian ini dilakukan secara dinamis dan bertahap serta terjalin secara terus-menerus. Dalam pengumpulan data diperlukan teknik sampling secara purposif (purposive sampling) (Bogdan \& Biklen, 1992: 67), yang diimplementasikan melalui disain funnel (Bogdan \& Biklen, 1992: 186), dan teknik sampling bola salju (snowball sampling), serta sampling waktu (time sampling).

Metode berisi jenis metode atau jenis pendekatan yang digunakan, uraian data kualitatif dan/atau kuantitatif, prosedur pengumpulan data, dan prosedur Teknik analisis data. Secara sederhana, sampaikan cara ilmiah dalam mencari dan mendapatkan data dan memiliki kaitan dengan prosedur dalam melakukan penelitian dan teknis penelitian yang ditulis dengan bahasa jelas, padat, dan ringkas, tidak teoritis, tapi dengan penggunaannya secara praktis. 


\section{HASIL DAN PEMBAHASAN}

\section{Nilai-nilai yang diprioritaskan dalam pendidikan karakter pada ketiga situs penelitian}

Tidak dapat dipungkiri lagi bahwa sekolah memiliki peranan dan dampak yang sangat penting terhadap karakter siswanya. Kenyataan ini menjadi entry point untuk menyatakan bahwa sekolah mempunyai tugas dan tanggung jawab yang lebih untuk melakukan pendidikan moral dan pembentukan karakter. Dalam menjalankan pendidikan karakter, yang dibutuhkan bukanlah banyaknya perilaku atau nilai yang dikembangkan, tetapi yang lebih penting adalah adanya pembiasaan yang dapat dilakukan yang pada akhirnya akan membentuk karakter yang kuat pada setiap siswa.

Karakter juga menunjukkan bagaimana seseorang bertingkah laku. Apabila seseorang berperilaku tidak jujur, kejam, atau rakus, dapatlah dikatakan orang tersebut memanisfestasikan perilaku buruk. Sebaliknya, apabila seseorang berperilaku jujur, bertanggung jawab, suka menolong, tentulah orang tersebut memanifestasikan karakter mulia. Istiah karakter juga erat kaitannya dengan 'personality'. Seseorang baru bisa disebut 'orang yang berkarakter (a person of character) apabila tingkah lakunya sesuai dengan kaidah moral. Dengan demikian, pendidikan karakter yang baik, harus melibatkan bukan saja aspek pengetahuan yang baik (moral knowing), tetapi juga merasakan dengan baik atau loving the good (moral feeling) dan perilaku yang baik (moral action). Penekanan aspek-aspek tersebut diperlukan agar peserta didik mampu memahami, merasakan dan mengerjakan sekaligus nilai-nilai kebajikan, tanpa harus didoktrin apalagi diperintah secara paksa.

Dalam dunia pendidikan saat ini, konsep pendidikan karakter sudah menjadi trend tersendiri yang bisa diterapkan dalam lembaganya masing-masing. Diantaranya sebagaimana yang sudah diterapkan di tiga situs pendidikan penelitian ini, yaitu MA An-Nur Bululawang, MAN 3 Malang dan SMAN 1 Malang. Ketiga situs ini berupaya mengajarkan konsep real life experiences dalam kehidupan sehari-hari. Konsep ini diajarkan dalam bentuk pemberian suri tauladan atau siswa diajarkan secara langsung pengalaman-pengalaman kehidupan yang nyata. Yang paling menonjol dalam konsep real life experiences adalah apa yang telah dilakukan MA An Nur dengan konsep pendidikan berasarama (pesantren), dengan kata lain Madrasah tidak hanya tempat mengajarkan dan belajar nilai-nilai kebaikan, mereka juga mendapatkan pengalaman yang nyata di asrama (pesantren).

Menurut Maxwell (dalam Muhaimin, dkk, 2011) karakter yang baik lebih dari sekedar perkataan, melainkan sebuah pilihan yang membawa kesuksesan. Ia bukan anugerah, melainkan dibangun sedikit demi sedikit, dengan pikiran, perkataan, perbuatan, kebiasaan, keberanian usaha keras, dan bahkan dibentuk dari kesulitan hidup. Berdasarkan hasil wawancara dan observasi lapangan di ketiga situs ini juga ditemukan bahwa apa yang sudah dilakukan oleh pihak sekolah sebagian besar sudah mencakup penerapan beberapa pendidikan karakter yang ada. Karakter yang paling banyak diterapkan di sekolah ini adalah lebih banyak karakter yang berbasis dengan nilai-nilai agama seperti jujur dan ketaatan beribadah (religius) sehingga karakterkarakter keagamaan sudah tertanam secara otomatis dan sudah ada sejak dini.

Kejujuran adalah kemampuan seseorang untuk menyatakan sesuatu yang benar itu adalah benar dan yang salah itu adalah salah. Begitupun kejujuran di lingkungan civitas akademika. Sebagai contoh, siswa dilarang melakukan plagiasi atau mencontek 
ketika ujian atau mengerjakan soal di kelas. Adapun pembiasaan yang dilakukan adalah dengan stop mencontek, stop plagiasi. Stop berbohong berani mengatakan apa adanya, tanpa ditutup-tutupi, ditambah atau dikurangi. Hal yang sama juga diartikan oleh Tim BP3KKPN (2010) bahwa "religisiusitas diartikan sebagai sikap dan perilaku yang patuh dalam melaksanakan ajaran agama yang dianut, toleran terhadap pelaksanaan ibadah agama lain, dan hidup rukun dengan pemeluk agama lain. Sementara jujur diartikan sebagai perilaku yang didasarkan pada upaya menjadikan dirinya sebagai orang yang selalu dapat dipercaya dalam perkataan, tindakan, dan pekerjaan". Menurut Ari Ginanjar Agustian (dalam Muhaimin, dkk, 2011) “dengan teori ESQ menyodorkan pemikiran bahwa setiap karakter positif sesungguhnya akan merujuk kepada sifat-sifat mulia Allah, yaitu al-Asma al-Husna. Sifat-sifat dan namanama mulia Tuhan inilah sumber inspirasi setiap karakter positif yang dirumuskan oleh siapapun". Dari sekian banyak karakter yang bisa diteladani dari nama-nama Allah itu, Ari merangkumnya dalam 7 karakter dasar, yaitu jujur, tanggung jawab, disiplin, visioner, adil, peduli, dan kerja sama.

Karakter lain yang diajarkan adalah disiplin dalam bertindak efektif dan efisien. Hal ini diwujudkan dalam mengatur kegiatan akademik, efektif mengikuti kegiatan akademis di Madrasah dan asrama (pesantren). Begitu pula terkait administrasi semua arsip (manajemen arsip) di unit madrasah/sekolah yang siswa ikuti sehingga mereka berupaya selalu disiplin dalam membuat, mendisdribusikan, dan menyimpan berkas kegiatan yang sudah ada sebagai bukti fisik dari setiap kegiatan atau program yang sudah terlaksana di unit siswa madrasah tersebut, hal ini dibuktikan dengan adanya unit kantor Jaminan Mutu terutama pada SMA 1 dan MAN 3 Jalan Bandung. Menurut Husen (2010) kedisiplinan diartikan sebagai sikap diri untuk selalu tepat waktu dan selalu mentaati aturan dengan kesadaran yang tinggi dan tanggung jawab. Bahkan karakter tanggung jawab juga sangat tampak dalam kehidupan di ketiga tempat penelitian ini. Adalah kemampuan merespon atau "ability to respon", artinya memberikan perhatian kepada orang lain, dan memperhatikan kebutuhannya. Berbekal dengan kejujuran dan sikap terbuka, seseorang akan berani mengambil resiko dari setiap kata dan perbuatannya. Ia berani melakukan apa saja dengan penuh rasa tanggung jawab. Perwujudannya adalah pribadi yang tampil dalam sikap berani, (bukan nekat atau pengecut), tegar, sabar, dan bersih diri. Konsep pendidikan karakterkarakter yang ada di atas memiliki esensi dan makna yang sama dengan pendidikan moral dan pendidikan akhlak. Tujuannya adalah membentuk pribadi anak, supaya menjadi manusia yang baik, warga masyarakat, dan warga negara yang baik. Oleh karena itu, hakikat dari pendidikan karakter adalah pedidikan nilai dalam rangka membina kepribadian generasi muda (T. Ramli dalam Husen, 2010).

\section{Model pendidikan karakter yang dilakukan melalui integrasi ke dalam kegiatan pembelajaran pada masing-masing mata pelajaran pada ketiga situs penelitian}

Untuk mewujudkan pendidikan karakter yang dilakukan secara berkelanjutan (continually) tersebut diperlukan model-model pendidikan karakter yang terintegrasi, yaitu: integrasi ke dalam proses pembelajaran pada semua mata pelajaran, kegiatan pembinaan kesiswaan (ekstra), serta budaya dan pengelolaan sekolah. Paparan kali ini berkaiatan dengan pendidikan karakter secara terintegrasi di dalam proses pembelajaran. Pendidikan karakter secara terintegrasi di dalam proses pembelajaran 
adalah pengenalan nilai-nilai, fasilitasi diperolehnya kesadaran akan pentingnya nilainilai, dan penginternalisasian nilai-nilai ke dalam tingkah laku peserta didik sehari-hari melalui proses pembelajaran baik yang berlangsung di dalam maupun di luar kelas pada semua mata pelajaran. Dengan demikian, kegiatan pembelajaran, selain untuk menjadikan peserta didik menguasai kompetensi (materi), juga dirancang dan dilakukan untuk menjadikan peserta didik mengenal, menyadari/peduli, dan menginternalisasi nilai-nilai dan menjadikannya perilaku.

Salah satu sarana untuk mengimplementasikan pendidikan karakter adalah pada kegiatan pembelajaran di kelas, dengan menjadikannya sebagai satu mata pelajaran tersendiri. Mata pelajaran ini unik dalam arti berbeda dengan mata pelajaran lain. Mata pelajaran ini berorientasi pada pengembangan karakter bagi siswa dengan menjadikan teladan dan berbuat sebagai basis pendidkan. Menurut Muslich (2011), guru secara sistematis dan sistemik mengintegrasikan nilai-nilai budi pekerti dalam materi pelajaran, sesuai dengan pelajaran yang diampuhnya. Untuk menumbuhkan nilai budi pekerti dalam diri siswa penyampaiannya harus dalam suasana kondusif dan dalam kehidupan sehari-hari di sekolah. Guru harus mampu menjadi tauladan berbudi pekerti yang luhur karena lembaga sekolah sebenarnya bisa dijadikan sebagai laboratorium pendidikan karakter.

Pada dasarnya, setiap situs pendidikan sedikit banyak sudah mengajarkan dan menerapkan konsep pendidikan karakter. Silabus atau RPP madrasah sudah menggabungkan antara kurikulum muatan lokal dengan pendidikan karakter meskipun secara aplikatif pengukurannya kurang bisa berjalan dengan baik. Dalam model pendekatan ini, pendidikan karakter dianggap sebagai mata pelajaran tersendiri. Oleh karena itu, pendidikan karakter memiliki kedudukan yang sama dan diperlakukan sama seperti pelajaran atau bidang studi lain. Dalam hal ini, guru pada semua bidang studi harus mempersiapkan dan mengembangkan kurikulum, mengembangkan silabus, membuat Rancangan Proses Pembelajaran (RPP), metodologi pembelajaran, dan evaluasi pembelajaran yang berbasis karakter. Konsekuensinya pendidikan karakter harus dirancangkan dalam jadwal pelajaran secara terstruktur. Kelebihan dari pendekatan ini antara lain materi yang disampaikan menjadi lebih terencana matang/terfokus, materi yang telah disampaikan lebih terukur. Hal yang sama juga dikemukakan oleh Washington, et.all, 2008 (dalam Muhaimin, dkk, 2011) bahwa pendidikan karakter ini bisa disampaikan dalam wujud terintegrasi dalam setiap bidang pelajaran, oleh karena itu menjadi tanggung jawab semua guru. Dalam konteks ini setiap guru dapat memilih materi pendidikan karakter yang sesuai dengan tema atau pokok bahasan bidang studi. Melalui model ini, setiap guru adalah pengajar pendidikan karakter tanpa kecuali. Pada setiap bidang studi, setiap guru ikut bertanggung jawab akan penanaman nilai-nilai hidup kepada semua siswa, di samping itu pemahaman akan nilai-nilai pendidikan karakter cenderung tidak bersifat informatif-kognitif, melainkan bersifat aplikatif sesuai dengan konteks pada setiap bidang studi. Dampaknya siswa akan lebih terbiasa dengan nilai-nilai yang sudah diterapkan dalam berbagai setting. Namun, menjamin kesamaan bagi setiap guru adalah hal yang tidak mudah, hal ini mengingat latar belakang setiap guru yang berbeda-beda. Sebagaiman yang terjadi pada MAN 3 Malang, menurut bapak Barik, sebagai guru fisika beliau berupaya memasukan unsur-unsur nilai agama dalam mata 
pelajaran fisika. Namun yang dilakukan adalah bukan mengajarkan agama, tetapi nilainilai agama yang bisa diintegrasikan dalam pelajaran fisika.

Menurut Howard Kirschenbaum dalam salah satu bukunya, "100 Ways to Enhance Values and Morality in Schools and Youth Settings" (1995) juga menguraikan beberapa cara untuk bisa meningkatkan nilai dan moralitas (karakter/akhlak mulia) di sekolah yang bisa dikelompokkan ke dalam lima metode, yaitu: 1) inculcating values and morality (penanaman nilai-nilai dan moralitas); 2) modeling values and morality (pemodelan nilai-nilai dan moralitas); 3) facilitating values and morality (memfasilitasi nilai-nilai dan moralitas); 4) skills for value development and moral literacy (ketrampilan untuk pengembangan nilai dan literasi moral; dan 5) developing a values education program (mengembangkan program pendidikan nilai). Berdasarkan pendapat Kirschenbaum ini para guru di sekolah perlu meningkatkan kualitas pembelajaran yang menginternalisasikan nilai-nilai akhlak mulia (karakter) pada siswa. Para guru secara bersama-sama perlu merancang pembelajaran di kelas dan di luar kelas yang dapat memfasilitasi siswa agar dapat membiasakan karakter atau akhlak mulia.

\section{Model pendidikan karakter yang dilakukan melalui pembiasaan dalam kehidupan keseharian di sekolah/madrasah dan integrasi ke dalam kegiatan pengelolaan sekolah/madrasah pada ketiga situs penelitian}

Penanaman nilai-nilai pendidikan karakter dapat juga ditanamkan di luar kegiatan pembelajaran formal. Pendekatan ini lebih mengutamakan pengolahan dan penanaman nilai melalui suatu kegiatan untuk dibahas dan kemudian dibahas nilainilai hidupnya. Model kegiatan demikian dapat dilaksanakan oleh guru sekolah yang diberi tugas tersebut atau dipercayakan kepada lembaga lain untuk melaksanakannya. Kelebihan pendekatan ini adalah siswa akan mendapatkan pengalaman secara langsung dan konkrit. Kelemahannya adalah tidak ada dalam struktur yang tetap dalam kerangka pendidikan dan pengajaran di sekolah, sehingga akan membutuhkan waktu yang lebih lama dan biaya yang lebih banyak (Husen, dkk, 2010). Budaya sekolah/madrasah merupakan salah satu aspek yang berpengaruh terhadap perkembangan peserta didik. Yang terpenting adalah iklim atau budaya sekolah/madrasah. Jika suasana sekolah/madrasah penuh kedisiplinan, kejujuran, kasih sayang, hal ini akan menghasilkan karakter yang baik. Pada saat yang sama, pendidik akan merasakan kedamaian dan suasana sekolah/madrasah seperti itu akan meningkatkan mutu pengelolaan pembelajaran. Dengan pengelolaan pembelajaran yang baik, akan menyebabkan prestasi akademik yang tinggi. Sebuah temuan penting lainnya adalah bila peserta didik memiliki karakter yang baik, akan berpengaruh langsung terhadap prestasi akademik yang tinggi. Oleh karena itu, langkah pertama dalam mengaplikasikan pendidikan karakter dalam sekolah/madrasah adalah menciptakan suasana atau iklim sekolah/madrasah yang berkarakter yang akan membantu transformasi pendidik, peserta didik, dan tenaga kependidikan menjadi warga sekolah/madrasah yang berkarakter. Hal ini termasuk perwujudan visi, misi, dan tujuan yang tepat untuk sekolah/madrasah. Visi dan misi sekolah/madrasah, kepemimpinan sekolah/madrasah, kebijakan dan manajemen serta partisipasi orang tua dan peserta didik, serta langkah dalam model pembelajaran nilainilai karakter akan saling berkontribusi terhadap budaya sekolah/madrasah. 
Penerapan pendidikan karakter yang didasarkan pada lingkungan akademis ini juga sangat tampak pada ketiga situs yang ada. Dengan demikian, pembelajaran nilainilai karakter ini tidak hanya pada tataran kognitif saja, tetapi menyentuh pada internalisasi dan pengamalan nyata dalam kehidupan sekitar siswa di lingkungan sekolah. Karakter yang tampak dalam lingkungan akademis ini lebih banyak berupa karakter religius. Di sini madrasah mengkondisikan lingkungan akademiknya yang bernuansa religi berupa pembacaan doa-doa sebelum mengawali aktifitas terutama aktifitas mencari ilmu. Konsep ini diterapkan dengan adanya satu siswa yang memimpin serta bersalaman (mencium tangan) pada guru menjelang masuk kelas dan sebelum pelajaran dimulai. Kegiatan pembacaan doa sebelum memulai pelajaran yang dilakukan di madrasah sudah sedikit banyak sudah mengajarkan konsep religiusitas siswa, karena sudah membiasakan budaya akademik yang Islami. Selain itu, penerapan pendidikan karakter ini juga diwujudkan dalam pemberian dukungan sarana penunjang baik yang bersifat fisik maupun non fisik. Lebih dalam (Rohmah, 2016) "perlu adanya perubahan pola pikir perguruan tinggi menjadi pola pikir yang mengikuti perubahan, yang berorientasi pada penciptaan budaya kerja yang lebih dinamis, produktif, dan kompetitif. Adapun beberapa strategi yang bisa ditempuh dalam rangka peningkatan budaya kerja agar lebih dinamis dan kompetitif, diantaranya; (1) menciptakan organisasi yang cerdas budaya, (2) membangun Karyawan agar memiliki semangat kompetisi yang dinamis, (3) meningkatkan kecerdasan emosi dalam membangun hubungan kerja, dan (4) meningkatkan komunikasi dalam menciptakan hubungan tim kerja".

\section{Model pendidikan karakter yang dilakukan melalui integrasi dengan kegiatan- kegiatan ekstra kurikuler pada ketiga situs penelitian}

Pendidikan karakter secara terintegrasi di dalam kegiatan pembinaan kesiswaan adalah pengenalan nilai-nilai (values), fasilitasi diperolehnya dengan kesadaran akan pentingnya nilai-nilai, dan penginternalisasian nilai-nilai ke dalam tingkah laku peserta didik melalui pelaksanaan kegiatan pembinaan kesiswaan, yaitu kegiatan pendidikan yang dilakukan di luar jam pelajaran tatap muka. Kegiatan tersebut dilaksanakan di dalam dan/atau diluar lingkungan sekolah/madrasah dalam rangka memperluas pengetahuan, meningkatkan keterampilan, dan menginternalisasi nilai-nilai atau aturan-aturan agama serta norma-norma sosial baik lokal, nasional, maupun global untuk membentuk insan yang seutuhnya.

Pendidikan karakter di SMA 1 pendidikan yang dikaitkan dengan kegiatan ekstrakurikuler diwujudkan dalam kegiatan pembinaan kemampuan berbahasa asing (Arab, Inggris, Jerman, Jepang, Prancis, Belanda dan Mandarin), olahraga dan pembinaan soft skill. Sementara di MA An Nuur cenderung menfokuskan pada pembinaan Bahasa Arab, sesuai dengan karakter pendidikan pesantrennya yang berbasis kitab kuning. Sementara di MAN 3 Jalan Bandung, dari pembinaan bahasa focus pada bahasa Arab dan Inggris. Ketiga situs juga mengembangkan kegiatan ekstra kurikuler, melalui pendidikan softskill, dalam hal ini siswa diharapkan mampu mengasah kreatifitasnya terutama di bidang teknologi. Yang menarik adalah di MA An Nur ada kesempatan bagi siswa yang belajar di Pesantren untuk magang pada berbagai unit usaha yang dimiliki pesantren, seperti koperasi, pembuatan tahu, dan unit usaha toko/minimarket. Menurut Muslich (2010), berdasarkan hasil penelitian di Harvard 
University AS (dalam Muhaimin, dkk, 2011) ternyata kesuksesan seseorang tidak semata ditentukan oleh pengetahuan dan kemampuan tehnis saja, tetapi lebih oleh kemampuan mengelolah diri dan orang lain (soft skill). Penelitian ini mengungkapkan bahwa kesuksesan hanya ditentukan sekitar 20 persen oleh hard skill dan sisanya 80 persen oleh soft skill. Bahkan orang-orang tersukses di dunia bisa berhasil dikarenakan lebih banyak didukung kemampuan soft skill daripada hard skill. Hal ini menunjukkan bahwa mutu pendidikan karakter tidak hanya ditempuh melalui pendidikan kurikulum saja melainkan juga melalui kegiatan ekstrakurikuler. Pada aspek olahraga, kerja keras juga menjadi salah karakter yang diajarkan pihak sekolah meskipun sarana yang digunakan adalah berupa olahraga. Selain itu, dalam olahraga ini pula terdapat penanaman nilai dan karakter kejujuran dan kedisplinan. Kejujuran ditunjukkan dengan berani mengungkapkan hasil yang diperoleh pada saat bertanding dengan benar, sementara kedisplinan tercermin dari sikap tepat waktu pada saat beraktifitas maupun berolahraga.

\section{Kendala-kendala yang dihadapi dalam implementasi pendidikan karakter dan solusi pemecahaannya pada ketiga situs penelitian}

Penerapan pendidikan karakter sebagaimana yang dijelaskan di atas ternyata tidak begitu saja terwujud. Banyak kendala yang dihadapi oleh ketiga situs pendidikan ini. Diantaranya kendala dalam hal pengambilan kebijakan. Menurut Ballantine (1993) dalam bukunya "the sociology of education" menyatakan bahwa individu-individu yang memegang posisi pada sebuah sistem pendidikan mempunyai pengaruh dalam hal pengambilan perubahan terkait dengan penerimaaan inisiatif dan menolak sebuah perubahan. Sehingga kendala yang dihadapi oleh situs di atas sangat mempengaruhi berjalan dan tidaknya penerapan pendidikan karakter ini. Karena sekolah selalu berhadapan dengan perubahan-perubahan dan tantangan, baik itu dari aspek internal lembaga maupun eksternal lembaga, karena itu flkesibiltas dan adaptasi mutlak diperlukan pada sebuah sistem pendidikan agar ia bisa tetap survive. Kendala lain yang dihadapi adalah pendidikan karakter yang ada di sekolah kurang bisa di dikonfersikan secara riil pada buku raport dan kurangnya monitoring dan evaluasi, sehingga pendidikan karakter ini masih sebatas normatif saja. Monitoring dalam hal ini bisa diwujudkan dalam bentuk bagaimana program itu dirancang, dilaksanakan, dievaluasi dan lapporkan. Bahkan kurangnya kontrol dan dukungan dari pihak keluarga masingmasing menjadi permasalahan tersebdiri karena setiap siswa pada saat di rumah tidak bisa dipantau sebagaimana yang dilakukan di madrasah.

Berdasarkan dari semua hasil di atas, pendidikan karakter di tiga situs pendidikan dapat digambarkan sebagai berikut: 


\section{Gambar 1: Nilai Karakter di Tiga Situs Penelitian}

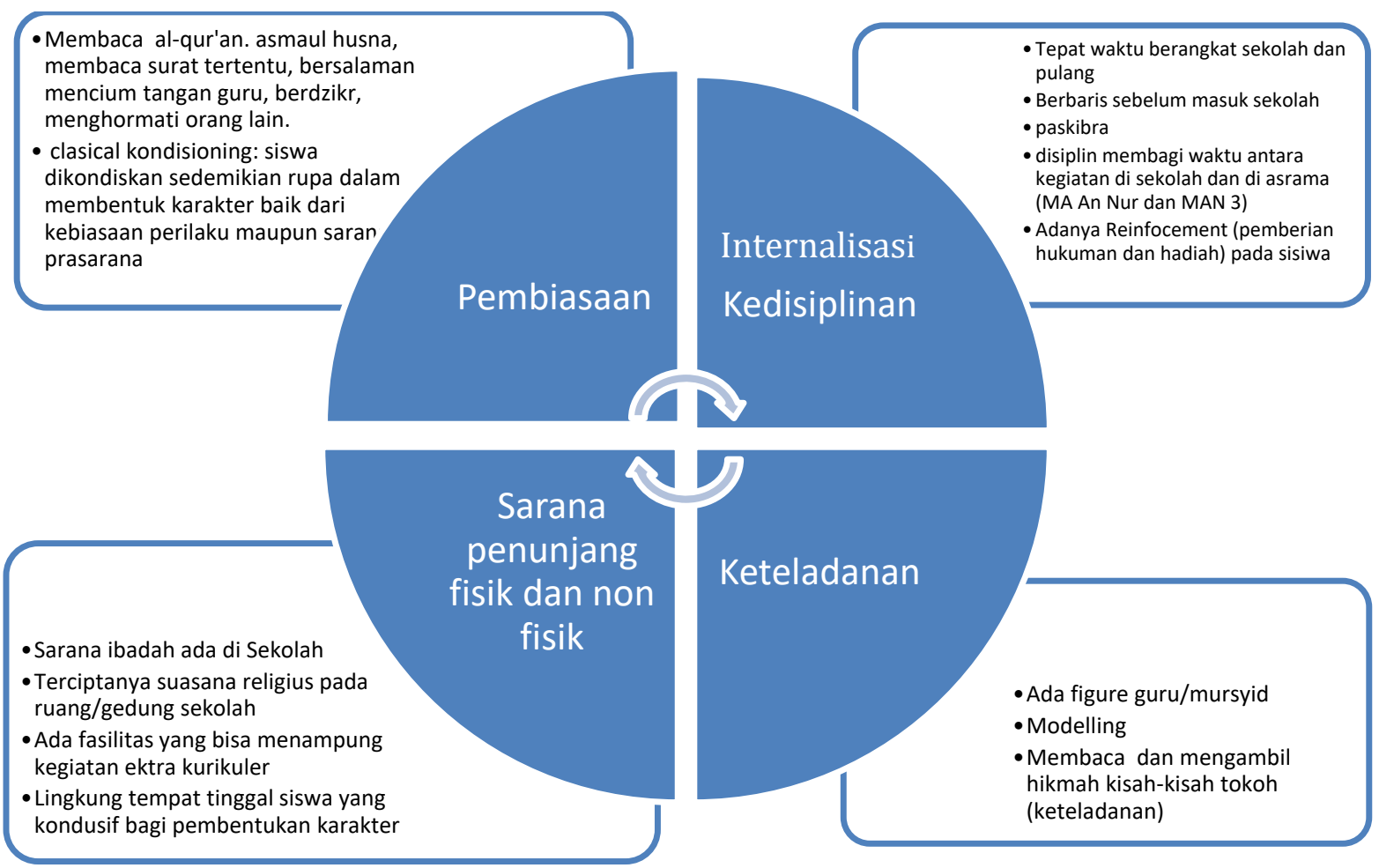

Setelah didiskusikan dengan beberapa literatur, diperoleh kedudukan sekolah/madrasah dalam rangka mewujudkan pendidikan karakter yang dapat digambarkan sebagai berikut:

Gambar 2: Model Penerapan Karakter di Tiga Situs Penelitian

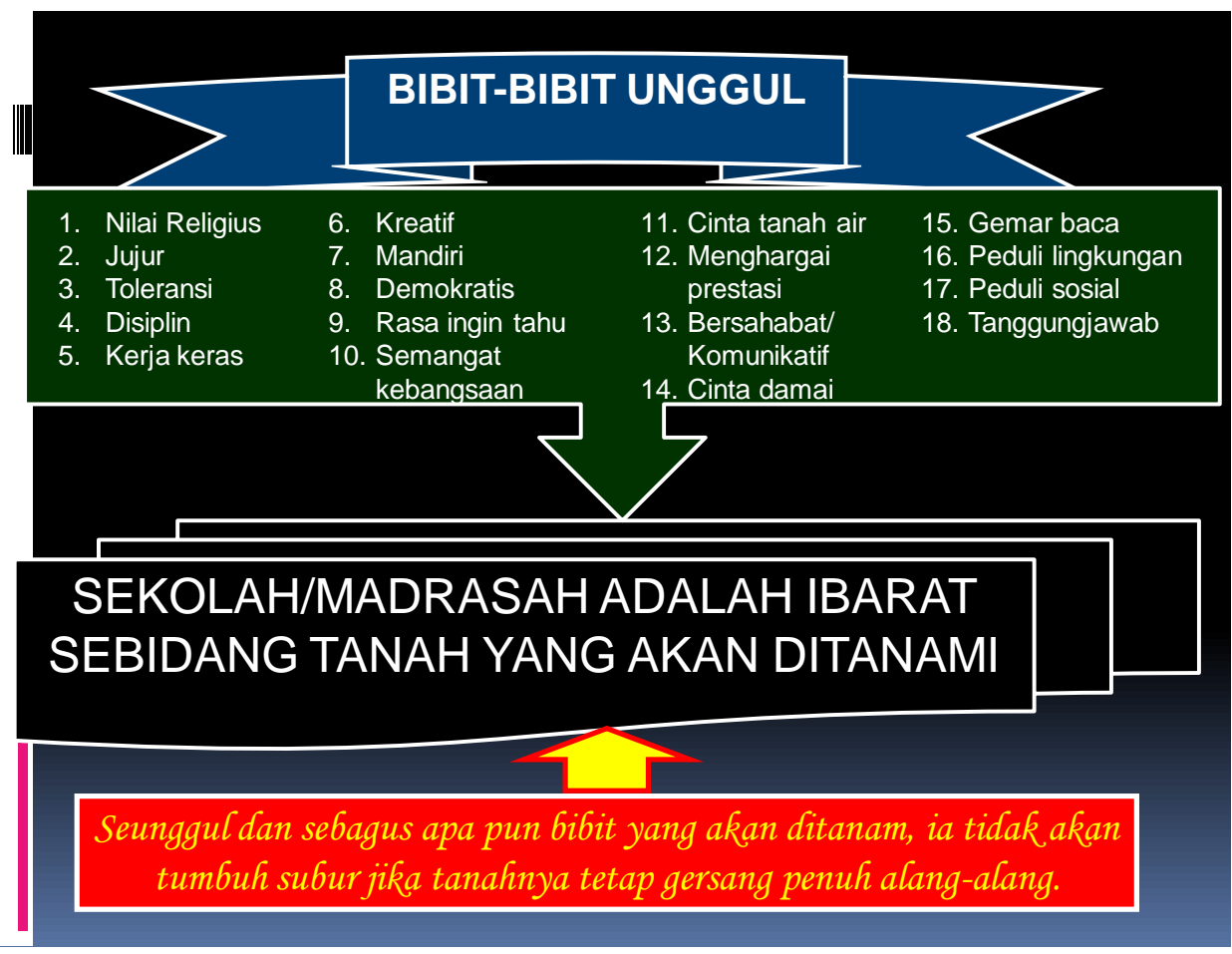

Vol. 5 No. 1, Juni 2020

J-MPI homepage: http://ejournal.uin-malang.ac.id/index.php/jmpi/index 


\section{KESIMPULAN}

Nilai-nilai yang diprioritaskan dalam pendidikan karakter adalah di MA An-Nur Bululawang, yaitu karakter Religius, Jujur, Disiplin, Kerja Keras, Toleransi, Mandiri, Cinta Tanah Air dan Demokrasi. Sementara di MAN 3 Malang, yaitu: Religius, Jujur, Disiplin, Kerja Keras, Cinta Tanah Air, Kerjasama, Kratif, Rasa Inging Tau, Menghargai Prestasi, Toleransi, Mandiri, Cinta Tanah Air dan Demokrasi. Dan di SMAN 1 Malang, yaitu pendidikan karakter kejujuran dan sikap toleransi lintas agama.

Model pendidikan karakter yang dilakukan melalui integrasi ke dalam kegiatan pembelajaran pada masing-masing mata pelajaran, yaitu MAN 3 Malang dalam bentuk pembuatan Silabus atau RPP madrasah yang sudah menggabungkan antara kurikulum muatan lokal dengan pendidikan karakter serta diwujudkan dalam bentuk tugas integrasi materi pelajaran yang harus dikaitkan dengan dalil-dalil agama. Model yang sama juga dilakukan oleh MA An-Nur Bululawang berupa (a) pembuatan kurikulum yang berbasis muatan lokal (mulok), (b) integrasi keilmuan umum dan agama. Sementara model yang ada di SMAN 1 Malang meski pendidikan karakter tidak tersirat dengan jelas, namun sesungguhnya sudah ada, dan sudah mulai masuk dalam karakter RPP, perilaku afektif dan psikomotorik.

Model pendidikan karakter yang dilakukan melalui pembiasaan dalam kehidupan keseharian di sekolah/madrasah dan integrasi ke dalam kegiatan pengelolaan sekolah/madrasah, yaitu di MA An-Nur Malang terlihat dari sekitar sekolahan yang ditemukan banyak kaligrafi, tulisan-tulisan arab, pepatah-pepatah, dan tulisan potongan-potongan ayat dan hadis yang tertempel di dinding-dinding sekolahan. Selain itu, Yayasan An-Nur mendesign kurikulum yang bercorak karakter pesantren, juga dengan traidisi pesantrenya. Di MAN 3 Malang, yaitu dengan banyaknya tulisan kaligrafi dan tulisan potongan-potongan ayat serta kata-kata mutiara dan juga mengkondisikan lingkungan akademiknya yang bernuansa religi berupa pembacaan doa-doa sebelum mengawali aktifitas terutama aktifitas mencari ilmu. Pendidikan karakter juga ditekankan pada siswa yang ada di asrama yang dianjurkan untuk selalu menggunakan beberapa bahasa asing (Arab dan Inggris) sebagai bahasa pengantar sehari-hari. Sementara pendidikan karakter yang dilakukan di SMAN 1 Malang lebih banyak pada pemberian dukungan sarana penunjang baik yang bersifat fisik maupun non fisik, seperti memasang fasilitas kran untuk berwudu' dan pada setiap sudut ruang memasang simbol-simbol keagaaman, membiasakan sholat dhuha dan sholat duhur berjamah di sekolah.

Model pendidikan karakter yang dilakukan melalui integrasi dengan kegiatankegiatan ekstra kurikuler pada ketiga situs penelitian, yaitu MA An-Nur Bululawang dengan konsep pendidikan bercorak pesantren. Selain kegiatan intra yang termuat dalam kurikulum dan mulok, sekolahan juga menyarankan siswa-siswanya untuk mengikuti kegiatan ekstra kurikuler yang ada. Bentuk pendidikan karakter lain di MA ini adalah menjalin kerjasama dengan Balai Latihan Kerja (BLK). Di MAN 3 Malang mengajarkan karakter melalui kegiatan ekstrakurikulernya serta melalui pendidikan teknologi yang diharapkan mampu memupuk tekad yang kuat menjadi pribadi yang mandiri. Sementara di SMAN 1 Malang diwujudkan dalam kegiatan pembinaan kemampuan berbahasa asing (Arab, Inggris, Jerman, Jepang, Prancis, Belanda dan Mandarin). 
Kendala-kendala yang dihadapi dalam implementasi pendidikan karakter dan solusi pemecahaannya pada ketiga situs penelitian, yaitu di MA An-Nur Bululawang. Posisi madarasah yang berada pada satu yayasan pesantran, yang menjadikan pengambilan kebijakan harus selalu meminta persetujuan dari pihak pesantren. Selain itu, pembagian waktu kegiatan juga menjadi kendala tersendiri. Sementara pendidikan karakter yang ada di MAN 3 Malang dianggap kurang berjalan secara efektif karna tidak bisa dikonfersikan secara riil pada buku raport dan kurangnya monitoring dan evaluasi, sehingga pendidikan karakter ini masih sebatas normatif saja. Sedangkan kendala yang dihadapi di SMAN 1 Malang berupa minimnya kontrol dan dukungan dari pihak keluarga siswa, sehingga setiap anak pada saat di rumah kembali "lepas" tidak bisa dipantau sebagaimana yang dilakukan di madrasah.

\section{REFERENSI}

Abrori, Husnan. (2018). Revitalisasi Kepemimpinan Untuk Meningkatkan Mutu Pendidikan Madrasah. J-MPI (Jurnal Manajemen Pendidikan Islam), Vol. 3 No. 2, Desember 2018.

Ajat Sudrajat, Marzuki. (2010). Model Pembentukan Kultur Akhlak Mulia Siswa Sekolah Menengah Pertama di Indonesia. Jurnal Kependidikan UNY, Volume 40, Nomor 1, Mei 2010.

Bogdan, RC dan Biklen. SK. (1992). Qualitative Research for Educational to theory and methods. London: Allyn and Bacon. Inc.

BSNP. (2007). Pedoman Penilaian Untuk Lima Kelompok Mata Pelajaran.

Darmanto. (2019). Implementasi Penanaman Karakter Sholeh, Ilmuwan,dan Pemimpin Sebagai Ciri Khas Karakter Lulusan SDIT. J-MPI (Jurnal Manajemen Pendidikan Islam), Vol. 4 No. 2.

Denzin, N.K., \& Lincoln, Y.S., (1994). Hanbook of Qualitative Research. Thousand Oaks, California: SAGE Publications, Inc.

Dokumen Pedoman Pelaksanaan Kegiatan Kurikulum MAN 3 Malang Tapel 2010/2011.

Dokumentasi Rencana Pengembangan MAN 3 Malang Tapel 2010/2011.

Dokumen Strategi Pengembangan MAN 3 Malang Tapel 2010/2011.

Elkind, David H. dan Freddy Sweet. (2004). How to Do Character Education. http://www.googcharacter.com/Article_4.html

Howard Kirschenbaum. (1995). "100 Ways to Enhance Values and Morality in Schools and Youth Settings".

Jeanne H. Ballantine, 1993. The Sociology of Education a Systematic Analysis, Prentice Hall, Englewood, Clifs, Amerika

Kemdiknas. (2010). Poin-poin Sambutan dan Pengarahan Presiden RI Susilo Bambang Yudhoyono pada Puncak Peringatan Hardiknas di Istana Negara. Jakarta.

Kerangka Acuan Pendidikan Karakter, 2010. Direktorat Ketenagaan Direktorat Jenderal Pendidikan Tinggi Kementerian Pendidikan Nasional.

Lickona, Thomas. 1991. Educating for character: How our school can teach respect and responsibility. New York: Bantam books.

Lincoln, Y.S, \& E.G. Guba. (1985). Naturalistic Inquary. Beverly Hills: Sage Publication. 
Mansur Muslich. (2011). Pendidkan Karakter Menjawab Tantangan Krisis Multidimensional. Jakarta: Bumi Aksara.

Mawardi, Imam dkk. (2020). Penguatan Pendidikan Karakter (PPK) Berbasis Budaya Islami Sekolah Di Mi Muhammadiyah Sidorejo Bandongan. Jurnal Pengabdian Dan Pemberdayaan Masyarakat, Vol. 4 No. 1.

Muhaimin, M. Fahim Tharaba, Ahamad Nurul Kawakib, Muhammad Jamaluddin, dan Moh. Bahrun Amiq. (2011). Mencari Model Pendidikan Karakter Di Sekolah Studi Multisitus Pada Man 3 Malang, Sman 1 Malang Dan Ma An-Nur Bululawang Kabupaten Malang. Penelitian Universitas Islam Negeri Maulana Malik Ibrahim Malang.

Ningsih, Tutuk. (2019). Peran Pendidikan Islam Dalam Membentuk Karakter Siswa Di Era Revolosi Industri 4.0 Di Madrasah Tsanawiyah Negeri 1 Banyumas. Insania: Jurnal Pemikiran Alternatif Kependidikan, Vol. 24 No. 2.

Tim Badan Penelitian dan Pengembangan Pusat Kurikulum Kementerian Pendidikan Nasional. (2010). Pengembangan Pendidikan Budaya dan Karakter Bangsa.

Permendiknas nomor 19 tahun 2007 tentang Standar Pengelolaan Pendidikan.

Profil MAN 3 Malang Tapel 2011/2012

Profil MA an-Nur Bululawang Malang Tapel 2011/2012

Profil SMAN I Malang Tapel 2011/2012

Rohmah, Noer. (2016). Implementasi Penanaman Karakter Sholeh, Ilmuwan,dan Pemimpin Sebagai Ciri Khas Karakter Lulusan SDIT. J-MPI (Jurnal Manajemen Pendidikan Islam), Vol 1, No 2.

Taulabi, Imam dan Mustofa, Bustomi. (2019). Dekadensi Moral Siswa Dan Penanggulangan Melalui Pendidikan Karakter. Jurnal Pemikiran Keislaman, Vol. 30 No. 1, Januari-Juni 2019.

Trisnantari, Hikmah Eva dkk. (2019). Manajemen Peningkatan Mutu Pembelajaran Berbasis Karakter Dengan Sistem Full Day School (Fds). Jurnal Pendidikan Karakter, No. 1.

Trisnawati, Nika Fetria dan Sundari. (2020). Efektifitas Model Problem Based Learning dan Model Group Investigation dalam Meningkatkan Karakter Anti Korupsi. MOSHARAFA: Jurnal Pendidikan Matematika, Vol. 9 No. 2. 